IZA DP No. 8223

Job Displacement Insurance: An Overview

Donald O. Parsons

May 2014 


\title{
Job Displacement Insurance: An Overview
}

\author{
Donald O. Parsons \\ George Washington University \\ and IZA
}
Discussion Paper No. 8223
May 2014

IZA
P.O. Box 7240
53072 Bonn
Germany

Phone: +49-228-3894-0

Fax: +49-228-3894-180

E-mail: iza@iza.org

Any opinions expressed here are those of the author(s) and not those of IZA. Research published in this series may include views on policy, but the institute itself takes no institutional policy positions. The IZA research network is committed to the IZA Guiding Principles of Research Integrity.

The Institute for the Study of Labor (IZA) in Bonn is a local and virtual international research center and a place of communication between science, politics and business. IZA is an independent nonprofit organization supported by Deutsche Post Foundation. The center is associated with the University of Bonn and offers a stimulating research environment through its international network, workshops and conferences, data service, project support, research visits and doctoral program. IZA engages in (i) original and internationally competitive research in all fields of labor economics, (ii) development of policy concepts, and (iii) dissemination of research results and concepts to the interested public.

IZA Discussion Papers often represent preliminary work and are circulated to encourage discussion. Citation of such a paper should account for its provisional character. A revised version may be available directly from the author. 
IZA Discussion Paper No. 8223

May 2014

\section{ABSTRACT}

\section{Job Displacement Insurance: An Overview}

Earnings losses from permanent job separations are a serious threat to the financial security of long-tenured workers. Job displacement insurance is presumably designed to offset these losses, but evidence suggests that consumption smoothing among the long-tenured displaced is seriously incomplete, at least in lightly regulated labor markets. Unemployment and reemployment wage insurance could fully cover these losses, but are costly to provide. Severance pay has emerged as a supplemental, if much criticized, instrument. Moral hazard limitations on unemployment insurance generosity mean that severance pay functions as scheduled (partial) unemployment insurance and scheduled wage insurance. Consumption smoothing over time through savings and borrowing is less efficient than ideal insurance, but may be preferred in second-best situations. Long-tenured separated workers are older on average, which introduces special problems, but also additional policy options, including early access to retirement accounts.

JEL Classification: J65, J41, J33, J08

Keywords: job displacement, unemployment insurance, wage insurance, severance pay, insurance adequacy, early retirement

Corresponding author:

Donald O. Parsons

Economics Department

2115 G Street NW, Monroe Hall 368

Washington, DC 20052

USA

E-mail: dopars@gwu.edu 


\section{Introduction}

Earnings form the bulk of worker wealth in industrial economies and job displacement is a serious financial threat. Job displacement losses vary with the individual, the structure and flexibility of the labor market, and the business cycle, but are typically large and quite persistent among long-tenured workers. Although the economic risk of "job displacement from a long tenured job" is a real one to all workers, the fraction that experience the event is not large. ${ }^{1}$ Many workers will never become long-tenured, and long-tenured workers may remain employed until disability or retirement ends their work-lives. Structurally the long-tenured displaced worker is likely to have held a job with relatively stable demand, punctuated by infrequent, but sharp permanent contractions.

Events that involve a small probability of a large loss are ideally insurance events, not saving or borrowing events. Earnings losses are usefully decomposed for insurance purposes into (i) those incurred through spells of unemployment, and (ii) those incurred through reemployment wage (rate) losses. Reemployment wage losses are apparently costly to insure, perhaps for administrative reasons, while unemployment losses are difficult to insure fully because of incentive problems deriving from the greater leisure available to the unemployed. If the utility value of benefits and the unemployed leisure is higher than that of working, incentives to seek and accept job offers fail (search moral hazard). ${ }^{2}$ Other distortions, often labeled "firing cost" effects, arise if the employer bears substantial expected separation costs.

Standard commercial insurance is rare for this risk, but employers, trade unions, and governments offer various consumption smoothing mechanisms. Each has its own limitations, and supply elements play an important role in the composite insurance that emerges to

\footnotetext{
${ }^{1}$ For his sample of displaced workers in their fifties (ages 51 to 60 ) in the U.S., Couch reports a two year job displacement rate of 4.7 percent, Couch (1998, p.10).

2 The resulting distortions can be dramatic if unemployment insurance rules are poorly written, Riddell and Kuhn (2010).
} 
moderate these risks. ${ }^{3}$ Employers can offer simple separation packages to displaced workers, and have one distinct advantage--they can avoid job displacement altogether by maintaining the worker on the job in low demand times (labor hoarding). ${ }^{4}$ Trade unions can negotiate guaranteed employment agreements or separation benefits and even provide benefits directly. However, employers and labor unions have one critical disadvantage, an inability to monitor worker activities following displacement, which is required for actual-loss-based unemployment and reemployment wage insurance. Governments can reasonably monitor reemployment, at least if labor markets are largely formal, but struggle with subtler information like the intensity of job search. As a consequence most separation packages involve only partial unemployment insurance. $^{5}$ Severance pay, fixed-sum payments at the time of separation, serves as both scheduled wage insurance and (partial) scheduled unemployment insurance in this second-best world. $^{6}$

The important function of severance pay as scheduled wage insurance is often neglected in theoretical studies. These studies fail to distinguish between temporary separations, which normally involve no wage rate losses, and permanent separations, which do. $^{7}$ For example, Azariadis (1974), Rosen (1985), and Blanchard and Tirole (2008) focus on contracting issues, and simplify by ignoring the reemployment market, essentially treating unemployment as an absorbing state. Shavell and Weiss (1979) and Shimer and Werning (2008) consider the behavior of unemployed workers only, so the models are silent on prior wages and therefore wage loss. Flemming (1978), Hansen and Imrohoroglu (1992), Hopenhayn and Nicolini (1997), and Pissarides (2010) introduce a reemployment market in a

${ }^{3}$ A detailed discussion of the job displacement insurance policy alternatives can be found in Parsons (2014a).

4 Excessive labor hoarding is the focus of its own literature, carrying the label firing costs.

${ }^{5}$ Card, Chetty, and Weber (2005) and Chetty (2008) raise provocative questions about the welfare implications of unemployment-insurance-induced increases in unemployment duration. Unemployment insurance effects may include income (liquidity) effects as well as the usual incentive effect that concerns most policy designers.

${ }^{6}$ Scheduled benefits mean fixed benefits linked to expected, rather than actual, losses.

${ }^{7}$ A detailed review of job displacement loss studies is provided below. 
contracting framework, but simplify by assuming that wages are the same for workers pre and post layoff, permitting them to focus on unemployment.

Governments are quite active in this insurance market, often mandating that firms provide severance pay and, less frequently, directly supplying unemployment; a summary of these efforts is provided below. The success of these measures in smoothing consumption following job displacement of long-tenured workers is more problematic. Cochrane (1991), using a general consumption approach proposed by Mace (1991), screened the U.S. for specific adverse events and identified involuntary job loss and, to a lesser extent, long-term illnesses (greater than one hundred days) as being especially poorly "insured." A number of consumption studies, surveyed below, confirm Cochrane's finding. At least in U.S. style economies (U.S., U.K, and Canada), long-tenured displaced workers experience large average declines in consumption.

One demographic group is of special interest. Long-tenured displaced workers are disproportionately older and may be eligible for disability and retirement benefits, with consequences for labor force participation and consumption smoothing. The decline in health status and marketable skills that often comes with age, when combined with the private and public income support systems meant to ease the impact of these declines on consumption, makes these workers an especially attractive policy target. Like private firms, governments often reduce the aggregate workforce by encouraging "early retirement," especially when unemployment is high.

\section{Job Displacement Losses}

There are a variety of reasons for job separation, with quite different consequences for earnings. Layoffs (employer-initiated job separations without cause) are the main focus here, and must be distinguished from quits (employee-initiated job separation), discharges (employerinitiated job separations with cause), and other separations, including most prominently 
retirement. $^{8}$ Quits (voluntary separations from the perspective of the worker) are often advantageous to the worker. Discharges for cause are not, but for obvious reasons employers are averse to subsidizing such separations. Retirement carries the expectation that the worker will leave the labor force, and often involves employer, union, or government financial support independent of job displacement insurance. Within separation categories, distinctions are also important, including that between permanent and temporary layoffs. Permanent layoffs are synonymous with job displacements. Temporary layoffs, common in the United States and Canada, are layoffs expected to result in rehire, often after a known time period.

Job displacement losses are often substantial. Consider the recent experience of job displacements of long-tenured workers (three or more years of tenure at displacement) in the United States, derived from the Bureau of Labor Statistics' Displaced Workers Survey. Of the long-tenured displaced from 2009 to 2011, only 56 percent were employed in January of 2012, with another 26.7 percent unemployed, and the remainder (17.4 percent) out of the labor force altogether, BLS (2012). The fraction out of the labor force jumps dramatically among workers 55 years of age and older, Figure1, Panel A. Among displaced workers from full-time wage and salary jobs who were employed in January 2012, 26.6 percent suffered wage losses of 20 percent or more, Figure 1, Panel B.

\section{$<$ Figure 1>}

Economists have devoted considerable attention to the structure of these losses; a few key studies are summarized in Table 1. The paradigm study is that of Jacobson, LaLonde, and Sullivan (1993a), who used administrative data to capture important elements of the dynamics of job displacement loss. ${ }^{9}$ Long-tenured workers (six years of tenure or more) suffered earnings losses that begin well before displacement, with a sharp earnings drop at displacement,

\footnotetext{
8 These are U.S. Bureau of Labor Statistics definitions. Elsewhere BLS layoffs are often called redundancies.

9 Jacobson, LaLonde, and Sullivan (1993b), Fallick (1996), Kletzer (1998), and Kuhn (2002) provide surveys of the literature.
} 
followed by a lengthy, incomplete recovery. As they reported, "We find that high-tenured workers separating from distressed firms suffer long-term losses [six years following displacement] averaging 25 percent per year." Jacobson, LaLonde, and Sullivan (1993a, p.685). ${ }^{10}$ Short term earnings losses were much higher, 45 percent in the first quarter after displacement.

$<$ Table 1>

The Jacobson, LaLonde, and Sullivan data represent a single state with a large heavymanufacturing sector (Pennsylvania) and may be atypical. Couch and Placzek (2010) replicated the JLS study on administrative data for Connecticut in a more robust, serviceoriented labor market and find that earnings losses are significantly lower. Couch and Placzek (2011, p.587) reported earnings losses of 32-33 percent in the quarter after displacement and 13-15 percent six years later. The lower loss estimates are to be expected given the countercyclical property of job displacement earnings losses, Davis and Von Wachter (2011). The basic time profile of earnings losses was quite stable.

Studies based on survey data provide additional details of this process, including the partition of earnings losses into unemployment losses and wage losses. Ruhm (1991), using the PSID, reported persistence earnings losses following job displacement, on the order of 14.7 percent four years after job loss. With the survey data, Ruhm was able to break down the profile of losses by source. The high unemployment experienced following job loss had largely (85 percent) dissipated four years later, but earnings losses linked to wage rate losses remained large, with reemployment wages 14-15 percent below pre-separation earnings.

Stevens (1997), also using the PSID, provided details on the nature of this loss process-not only are the displaced often forced to accept entry level wages, the new job will almost by definition have no seniority rights, making workers vulnerable to additional spells of unemployment. She reported relative earnings losses among displaced workers with three or

\footnotetext{
${ }^{10}$ Losses are relative to a control group of retained workers.
} 
more years of tenure of 26 percent immediately following separation. Earnings losses of 11 percent remained 6 or more years after displacement, almost all wage (rate) losses, Stevens (1997, p.178).

The U.S. Job Displacement Surveys provide ample historical evidence of earnings losses (up to three years following displacement), both on average and by job tenure, Farber (2004). Average losses among the displaced included employment losses of 32 percent while wage losses among the full-time to full-time reemployed average 8 percent, Farber (2004, p.113 and p.115). Earnings losses varied widely across individuals, industries, and economic conditions. Indeed many individuals report wage gains, especially in good times, Helwig (2001).

Expected losses were systematically larger for long-tenured workers. Averaged over the first ten DW Surveys (1982-84 through 1999-2001), losses among full-time workers who secure full-time reemployment was 3.3 percent among workers with one to three years of tenure (relative to those with less than a year), 9.6 percent among those with 4 to 10 years, 18.6 percent for those with 11 to 20 years, and 24.7 percent among those with more than 20 years of tenure. ${ }^{11}$ Loss differentials by tenure appear quite stable over the business cycle, Figure 2.

$<$ Figure 2>

\section{Job Displacement Insurance across Economies}

Job separation packages vary widely across economies (2009), but not without logic, Table $2{ }^{12}$ The administrative convenience of severance pay-the government need only mandate that private employers provide the instrument--makes it especially popular. ${ }^{13}$ In a sample of 149 countries with a million or more inhabitants, 130 (87\%) had some form of mandated severance pay, including 27 that had both statutory severance and collectively

\footnotetext{
${ }^{11}$ Author's calculations from Farber (2004, Table 3, p.96-97). These are partial effects, controlling for gender, race, age, and years since displacement, for workers 20 years and older.

12 Holzmann et al (2012) provide a detailed empirical account of variations in the size and composition of separation packages world-wide.

${ }^{13}$ Severance pay has its own potential limitations, the firing cost problem, discussed in Section 7 below. Parsons (2013) provides a recent review of severance pay theory and empirics.
} 
bargained severance pay in a "significant manner," Holzmann et al (2012, Annex B). ${ }^{14}$ Another $13(9 \%)$ had only significant collective bargaining severance. ${ }^{15}$ Only six (4\%) had neither.

$<$ Table 2>

Unemployment insurance is more difficult to provide, and, not surprisingly, much less common. Of the 130 countries in the sample with statutory severance pay, only $61(47 \%)$ provided unemployment insurance, 69 did not. Another $8(6 \%)$ with statutory severance pay offered means-tested unemployment assistance. Of the 13 countries with only collectively bargained severance, 11 countries provided unemployment insurance and another unemployment assistance. None of the six countries that had neither statutory nor collectively bargained severance (the Democratic Republic of the Congo, Iraq, Haiti, Lebanon, Gambia, and Timor-Leste) provided unemployment insurance.

The various combinations of unemployment insurance/assistance and mandated severance pay are not random, but are closely linked to country income and presumably government competencies. GDP per capita in the six countries that had neither mandated severance nor some form of unemployment insurance was only $\$ 1,999$. Of the 69 countries that had only mandated severance pay and no unemployment insurance, average GDP per capita was $\$ 5,810$. Of the 61 countries with both mandated severance and some form of unemployment benefit, the average GDP per capita (in 2009 U.S. dollars) was $\$ 14,418$.

\section{Insurance Adequacy}

On average displaced workers with long tenure suffer serious long-term earnings losses, which, in the absence of consumption smoothing instruments, will have adverse effects on household consumption. There are many such devices, private and public, and it is natural to ask how effective these efforts are at smoothing the consumption of displaced workers. A

\footnotetext{
${ }^{14}$ Author's calculation from Holzmann et al (2012, Annex B).

${ }^{15}$ This group includes the U.S., where collective bargaining agreements do often include severance pay provisions, Pita (1996), but where collective bargaining is limited. Voluntary plans are however prevalent, Bishow and Parsons (2004).
} 
number of consumption studies of displaced workers provide evidence on that question. Unfortunately these studies are limited to "Anglo-Saxon" countries (the U.K., Canada, and the U.S), which have broadly similar labor markets and social insurance systems. In all three countries, labor markets are relatively "flexible," unemployment insurance replacement rates are moderate, and severance pay is modest. ${ }^{16}$

Assessment studies focus on the consumption, not the utility, effects of displacement, no doubt in the belief that wage changes upon reemployment will have only modest effects on work hours. The U.S. study by Cochrane (1991) flagged job displacement as an especially serious threat to consumption stability. "Households that experienced an involuntary job loss had consumption growth 24-27 percentage points lower than households that did not..." Cochrane (1991, p.969). Other studies, directly focused on the negative consumption effects of job displacement, confirmed that they are substantial. Stephens, for example, tracked out the impact of job loss ("plant closed/employer moved" and "laid off/fired") on earnings and on consumption over time in the U.S. (PSID). He found a long term decline (six years after displacement) in the earnings of the household head of 21.9 percent, with a decline in family food consumption of half that amount, or 11 percent, Stephens (2001, p.33). Among older workers (age 50 to early 60s). the relative change (loss) in annual food consumption within one year of job loss was 15\% (PSID) to 17.5\% (HRS), Stephens (2004, p.268).

$<$ Table 3>

Consumption studies using Canadian and U.K. data revealed similar regularities. Browning and Crossley (2008), using Canadian data, assess the impact on consumption of permanently displaced workers (plant closure and other mass layoffs). They reported consumption losses of about 6 percent relative to consumption growth for those laid off with known recall data. Losses were higher for workers with tenure greater than 10 years or age

\footnotetext{
${ }^{16}$ Severance pay is voluntary in the U.S. and, if offered, typically provides one to two weeks pay per year of service. Canada mandates one week pay per year of service, the U.K approximately one half week per year of service, Holzmann et al (2012, Annex B).
} 
greater than 40 (10 percent). Bloemen and Stancanelli (2005) estimated a model of food consumption growth (from prior to layoff to three months after) in the United Kingdom, and report a decline in consumption of 17 percent.

Researchers have also estimated the impact of variations in job displacement insurance, especially unemployment insurance generosity, on consumption of the unemployed. Presumably consumption will vary (positively) more closely with benefits the more critical the benefits are as consumption support when earnings drop. Browning and Crossley (2001), using the same Canadian data set discussed above, estimated the sensitivity of consumption to changes in the key unemployment benefit parameter, the replacement ratio. They reported almost no impact of UI generosity on consumption-an elasticity of 0.05 (a ten percent decrease in the replacement rate will induce a half a percent decrease in consumption). ${ }^{17}$ The effect was somewhat higher for vulnerable subgroups, 0.17 for example for sole breadwinner respondents who report no family assets.

Similarly, Bloemen and Stancanelli (2005) estimated the impact of more generous job displacement benefits on food consumption growth (from prior to layoff to three months after) in the United Kingdom. Severance pay ("end of job payment") had a positive and significant effect on consumption growth as well as debt reduction following job loss. The UI replacement rate was not significant if entered without interactions, but was significant if interacted with the importance of the respondent's income to the household. “...for a household where the head's earnings are the only source of income, a drop in the replacement rate of $10 \%$ leads to a $2 \%$ fall in food expenditure." (Bloement and Stancanelli (2005), p.443).

Blundell, Pistaferri, and Preston (2008) extended this literature (PSID) in a general way, noting that:

17 Gruber (1997) reported extremely large UI replacement rate effects on consumption in the U.S. (consumption elasticity with respect to UI benefits of 0.25 for the whole population), but this estimate is inconsistent with later estimates and should probably be treated as an aberration. 
We find some partial insurance of permanent shocks, especially for the college educated and those near retirement. We find full insurance of transitory shocks except among poor households. Blundell, Pistaferri, and Preston (2008, 1887)

These results are consistent with the belief that the temporarily unemployed workers and shorttenured, displaced workers find ways to cushion the effects of earnings shocks on household consumption, but that the long term displaced do not, with the (partial) exception of the college educated and those near retirement.

Apparently the mixture of private and public severance pay and unemployment insurance offered in the countries studied does not guarantee consumption stability in the face of job loss among long-tenured workers. Severance pay and perhaps unemployment benefit levels do appear to contribute to consumption smoothing. It is of course simple to design a system that would insure uninterrupted consumption following job displacement-offer unemployment benefits of unlimited duration equal to the original wage, because the worker would have no incentive to accept a lower offer. Such a plan would however would insure that the long-tenured displaced do not return to work, except in robust labor markets. The policy challenge is to design systems that will better insure the long-tenured displaced without wasting their productive capacities. In the remainder of this review, alternative job displacement insurance systems are considered within a standard demand and supply framework.

\section{The Insurance Market}

\section{5a. Insurance Demand}

The capitalized value of expected job displacement losses of long-tenured workers will vary with discount rates and potential years of remaining work-life, but are large for all but those close to retirement. The literature focuses on employer and government efforts to provide consumption smoothing devices, but individual efforts are non-trivial. At the elementary level, multi-earner households pool resources, though the pools are generally quite small. Households also adjust labor market behaviors, with other family members entering the workforce to offset the earnings losses of those displaced. 
For frequent, small loss events--temporary layoffs and displacement of short-tenured workers--savings and credit instruments may be quite satisfactory. Saving instruments are abundant in industrialized economies, but third party borrowing opportunities are naturally limited by the likelihood the loan will be paid back. ${ }^{18}$ As instruments provided by employers, unions, and especially government have become dominant, studies of these informal approaches have evolved into the question--do public efforts crowd out informal efforts or do they contribute on net to worker financial security, Cullen and Gruber (2000) and Engen and Gruber (2001)? Apparently crowd out effects are substantial.

Because layoff in the first instance is an employment event, it is natural to imagine the issue within an employment contracting framework. ${ }^{19}$ In a simple single-period model, the worker and the employing firm negotiate a contract that specifies (i) the conditions under which the worker will be retained in the firm with corresponding wages, and (ii) the separation benefits to be paid if the worker is laid off, Parsons (2014b). Unemployment is an important aspect of this model, and worker utility is correspondingly multidimensional (consumption and leisure). The worker is assumed to be risk averse, and the firm risk neutral. ${ }^{20}$

A key issue is the severity of the demand shock that will induce the firm to lay off workers. Layoff behavior, or conversely job retention, has been much studied, in part because of the link with firing cost concerns, Section 7 below. Azariadis (1975), in his seminal work on employment contracting, derived the conditions under which the firm will lay off workers in an economy in which (i) there is no possibility of reemployment and (ii) job displacement insurance is not available. His model highlights the insurance value of labor hoarding: workers will negotiate full employment contracts over a larger domain of shocks.

\footnotetext{
${ }^{18}$ See Gruber (2001) for a description of financial assets upon entering unemployment and Sullivan (2008) for a discussion of access to unsecured credit (credit cards) among the unemployed.

19 Reviews of the employment contracting literature include Parsons (1986), Malcomson (1999), and Salanié (2005).

${ }^{20}$ In simple cases, two dimensional (consumption, leisure) "risk averse" can be defined by an indirect utility function that is concave in income, Stiglitz (1969), in this case full income--nonearned income plus earnings if the worker devotes all available hours to work.
} 
If demand contractions are sufficiently large, however, layoffs will occur and the displaced worker will find him- or herself unemployed or reemployed elsewhere, often at a lower wage. A complete separation package will then be a combination of

1. wage insurance, and

2. unemployment insurance.

The first-best magnitude of each of these is dependent on the structure of the state utility functions, sometimes labeled von Neumann-Morgenstern utility functions. Insurance redistributes consumption across states, but the utility value of consumption is in general not independent of the amount of leisure available to the worker, and the displaced worker by definition faces "excess" leisure in the unemployed state. Many design studies use a special case for this utility function, additively separable concave functions of consumption and of leisure. $^{21}$ This model has the convenient property that, if insurance can be costlessly provided, consumption will be equal across states in the ideal contract. If layoffs are justified, the ideal consumption plan can be implemented by

1. wage insurance benefits equal to the difference between the earnings of retained workers and reemployed workers, and

2. unemployment insurance benefits equal to reemployment earnings.

This special utility structure insures that search moral hazard problems will arise--consumption is equal across states of nature while leisure is greater in the unemployed state. ${ }^{22}$

\section{5b. Insurance Supply}

The usual third-party suppliers of insurance products do not exist for job displacement insurance. Instead three types of insurers are prominent: labor unions, employers, and the government. European trade unions were early pioneers in the provision of unemployment

${ }^{21}$ Early examples include Azariadis (1975), Shavell and Weiss (1979), and Hopenhayn and Nicolini (1997).

22 Perhaps to emphasize nontraditional concerns, Blanchard and Tirole (2008) employ a utility model with a constant cash equivalent value of leisure that induces neither search moral hazard nor firing cost problems (Section 7 below). 
insurance, but were never able to maintain reserves sufficient to finance benefits when times were hard. ${ }^{23}$ These failed efforts induced government intervention, the Ghent system, in which governments essentially financed union benefit programs. ${ }^{24}$ In the U.S., unions have negotiated guaranteed employment contracts as well as severance pay and supplements to governmentsupplied unemployment insurance benefits (supplemental unemployment benefits or SUB plans), Pita (1996). That said, today employers and governments are the main suppliers of job separation insurance.

The efficient provision of full job displacement insurance requires information on a variety of processes:

(i) was the worker involuntarily separated and therefore eligible for benefits?

(ii) is the worker, while on benefits, actively seeking the next job and willing to accept reasonable job offers he or she uncovers?

(iii) has the worker become reemployed, so that benefits can stop?

(iv) is the drop in earnings following reemployment the consequence of a decline in wage rate rather than reduced work hours?

The first question is most easily answered by the employer, though the employer's response may be distorted by self-interest, depending on the financing system. For example, if benefits are limited to involuntary separations and partly or wholly paid by the employer, the employer has an incentive to categorize a separation as voluntary. If the layoffs are large scale, involuntary separations are hard to disguise, but that is not the case in small numbers situations. Indeed, in the U.S. unemployment insurance system, employers bear a substantial share of the cost of benefits paid out to their own laid off workers (experience rating), and significant resources are required to adjudicate disputes over the nature of the separation. Conversely, if benefits are wholly paid by the government, the employer may be tempted to

\footnotetext{
${ }^{23}$ Willoughby (1897) provides an interesting contemporaneous account of these efforts.

${ }^{24}$ See ILO (1955) for a broader historical review of early public unemployment insurance programs.
} 
report any separation as involuntary, treating generously its own past workers at the expense of other taxpayers, typically firms.

Unemployment insurance requires substantial information following separation. The second and third questions seriously strain employer capabilities, and perhaps even those of governments. Even the conceptual simple task of determining whether the displaced worker has taken another job faces practical difficulties. In more developed economies, for example, undetectable jobs arise in the shadow economy of cash transactions. In less developed economies, tracking workers across jobs of any sort may be difficult. ${ }^{25}$ Governments may be efficient at monitoring employment if the shadow economy is small and UI program coverage is broad. In that case, the worker's reemployment would be entered into the system at the time of next hire, assuming of course unique individual identifiers.

Problem (ii) is not easily monitored by any agent and has been the focus of much program design effort. In the simplest case, unemployment involves a release from work, and actual loss UI benefits must be limited in order to induce appropriate search and job acceptance behavior, with the reduced UI benefits partly and imperfectly offset by scheduled benefits (severance pay), Baily (1977), Rogerson and Schindler (2002), and Parsons (2014b).

The provision of wage insurance pivots critically around the last question (iv), the answer to which is typically unavailable to the displacing firm and often to the government. ${ }^{26}$ The U.S. unemployment insurance system, for example, relies largely on earnings records for eligibility and benefit calculations, not on work hours. But wage insurance is really wage rate insurance and assumes a return to full-time work. Otherwise it becomes a variant of unemployment insurance with similar problems. The separation of total earnings into hours and wage rates is

\footnotetext{
${ }^{25}$ For recent estimates of the pervasiveness of the shadow economy, see Buehn and Schneider (2012)

${ }^{26}$ Full reemployment wage insurance would require pooling of the earnings of the winners and the losers, but this has not been seriously proposed. Most policy designers propose a negative option payment-for those who make losses, some fraction of the losses will be paid through premiums from all, Baily, Burtless, and Litan (1993). For additional discussions, see Parsons (2000), Kling (2006), and LaLonde (2007).
} 
not a serious problem in large enterprises, which must themselves accurately track worker activities, but can be more difficult to verify in smaller enterprises. In this environment, wage insurance benefits are likely to be "scheduled," that is based on expectation of loss, rather than actual loss.

In broad outline, then, information problems are likely to shift actual loss unemployment provision to the government and to transform the insurance package from unemployment insurance and wage insurance to (incomplete) unemployment insurance and severance pay. Severance pay functions as:

- $\quad$ scheduled (partial) unemployment insurance, and

- $\quad$ scheduled wage insurance.

\section{Insurance Market Problems}

\section{6a. Job Search and Offer Acceptance Incentives}

The concern that generous unemployment insurance benefits might discourage return to work has almost certainly limited unemployment benefits in countries that offer unemployment benefits. As a consequence a great deal of thought has gone into the consideration of alternative mechanisms for inducing appropriate job search and offer acceptance by the unemployed. Two approaches have received attention--sanctions and active labor market policies. Sanctions typically involve monetary penalties, often in the form of reduced benefits, while active labor market policies involve time penalties.

\section{i. Sanctions}

An obvious approach is to impose penalties or sanctions on those who do not behave appropriately. Sanctions can be in the form of fines or, more commonly, reductions in future benefits. ${ }^{27}$ Denying or delaying benefits to workers who quit or are fired from their last jobs before entering unemployment is one such sanction. The withholding of benefits if workers do

${ }^{27}$ Grubb (2000) provides a review of UI sanctions in OECD countries. 
not undertake, or at least report, reasonable job search effort is another. The penalty may be the same for workers who quit their jobs and those sanctioned for lack of search effort, Grubb (2000).

The U.S. unemployment insurance system has search requirements, which vary by state, with the loss of future benefits as the sanction. A plan might require the unemployed recipient to make three employer search contacts in one week. Such requirements are not realistically enforceable in the U.S.--it is apparently not possible to confirm or deny a large portion of claimed employer contacts, St. Louis, Burgess, and Kingston (1986). At a deeper level, it is a rare job that does not require some evidence of enthusiasm for the job by the applicant, but this is something easily withheld and impossible to monitor. Somewhat oddly, demonstration projects in the U.S. suggest that dropping the requirements entirely leads to large increases in unemployment duration, but requiring more than one search has no incremental impact on duration, Meyer (1995).

Abbring, van den Berg, and van Ours (2005) find, for the Netherlands, that the imposition of a sanction does significantly hasten the return to work, and moreover does so even after the current penalty has been lifted. They interpret this result to suggest that sanctioned workers perceive themselves as under extra scrutiny. One might imagine that wellpublicized sanctions may have similar threat effects on others.

\section{ii. Active Labor Market Policies}

An historically important technique for smoothing earnings shocks in limited information situations is public works, with the government providing employment to workers in the absence of private demand. Public works, used on a large scale in the U.S and elsewhere during the Great Depression and often by colonial powers in times of crop failure, remain a potential tool in 
less developed countries, Ravallion (1991). Even if the work yields little product, it assures the provider that the beneficiary is willing to work and is not employed elsewhere. ${ }^{28}$

The same approach has been extended to unemployment insurance beneficiaries under the label "active labor market policies," although the work activity might instead involve mandatory training or search activities. ${ }^{29}$ Search moral hazard arises because workers value leisure as well as consumption, and unemployment by definition includes excess leisure. If the government wants to direct income to the unemployed without discouraging work effort, it can do so by imposing a countervailing work (activity) requirement on the beneficiary. Such requirements are labeled "ordeals" by Nichols and Zeckhauser (1982).

As Besley and Coate (1993) nicely illustrate, ordeals work best, and perhaps only, if the insurer cares solely about income and consumption and not about worker utility, which would include leisure. For that reason, sanctions and ordeals appear in government mandated programs, not voluntary contracts in which utility is paramount. Modern applications of this public works approach often soften the edges of the policy by labeling the work activity "job training," although the evidence on positive earnings effects of government job training programs is decidedly mixed. The signature of an ordeal is that the activity be mandatory, not voluntary, although gradations exist here. One might conjecture that the more resources the government devotes to the activity, whether job training or counseling, the more effective the program and the less onerous the ordeal.

There is perhaps a natural limit to the ordeal of sanctions and active labor market policies. Imposing penalties on those one is trying to assist may be preferred to across-theboard benefit limitations, but is otherwise unappealing. In the best of circumstances, the threat

\footnotetext{
${ }^{28}$ Pissarides (2010) specifies conditions under which a private employer might undertake the equivalent of a public works project.

${ }^{29}$ See Kreiner and Tranaes (2005) for a discussion and analysis.
} 
of benefit sanctions or mandatory work requirements would induce ideal behavior without the threat ever being acted upon. ${ }^{30}$

\section{6b. Firing Cost Issues}

The importance of severance pay in the job displacement package is perhaps reflected in the pervasiveness of severance pay mandates, and the voluntary provision of severance where it is not mandated. Economists, however, have regularly expressed concerns about mandated severance pay. ${ }^{31}$ If employers must self-finance job displacement insurance, they might be tempted to retain workers in low demand states who would, on efficiency grounds, be released to secure more productive matches elsewhere. Labor hoarding may be excessive.

Firing costs are often associated exclusively with severance pay, but this is an historical accident. In a model in which employers supply all separation benefits and cannot reinsure those benefits in third-party markets, firing costs would be the sum of severance pay and expected unemployment benefits. The concern about severance pay distortions arose with the practice, common in much of Europe, of mandating that firms must provide severance pay, leaving firms to fully fund the mandate. The European unemployment system, in contrast, has no user cost element; firms can lay off workers without any concern that higher benefit payouts to their workers will lead to higher taxes or surcharges. In that situation, firing costs are limited to severance pay.

In the U.S., severance pay is voluntary and is fully financed by the employer, so the same firing cost concerns arise. Unemployment insurance benefits are fully funded by taxes on payrolls, but the tax rate varies with the UI benefits distributed to the firm's laid off workers ("experience rating") and will therefore enter firing cost calculations. Although severance pay is

\footnotetext{
${ }^{30}$ See for example Black, Smith, Berger, and Noel (2003). Such good fortune is perhaps rare.

31 See for example Emerson (1988) and Lazear (1990), and the reviews in Heckman and Pagés (2004), Holzmann, Pouget, Weber, and Vodopivec (2012), and Parsons (2012a).
} 
less generous in the U.S. than in Europe, the experience rating of unemployment benefits raises the possibility that firing cost distortions may be higher in the U.S.

As it happens, severance pay alone appears to have only modest effects on labor hoarding, although it is important to recognize that large benefit mandates are found only in countries in which labor laws are poorly enforced, Parsons (2012a). Neither do firms engage in active avoidance of severance mandates, a possibility proposed by Lazear (1990). Apparently they do not. That said, firing cost distortions may be a problem in substantially more generous benefit systems, an important caveat if one believes current levels are inadequate.

\section{Insurance Design}

A multi-period framework permits more complex insurance schemes as well as introducing savings and borrowing strategies. Embedding the insurance contract in a multiperiod context introduces direct effects on severance pay schedules and, more subtly, on unemployment insurance schedules. We consider insurance schemes in this section and saving and borrowing plans in the next.

\section{7a. Service Conditioned Severance Benefits}

The fact that reemployment wage losses increase systematically with job tenure, Figure 2 , has the unsurprising consequence that severance benefits are almost always increasing in "service" with the employer, essentially tenure. In voluntary plans in the U.S. a benefit rule of one or two weeks of pay per year of service is common, Parsons (2005). The same basic weeks-pay-per-year-of-service algorithm, though with greater benefit levels, is common in mandated severance world-wide. See the scatter diagram of mandated benefits at 20 years relative to 5 years, Figure 3, for the sample of mandated plans in medium and large countries (one million of more inhabitants, Holzmann et al (2012, Annex B). The typical mandate is, however, well in excess of 1 week per year of service. Of the 118 countries with severance mandates and valid non-zero benefit information at 20 years of service, 90 (76 percent) 
mandate more than 20 weeks pay, Holzmann et al (2012, Annex B). The median mandated benefit at 20 years of service in this sample of countries is 33.5 weeks pay.

$<$ Figure 3>

7b UI Benefits over the Duration of Unemployment

Of (much) greater design subtlety, multiperiod models introduce interesting new unemployment insurance benefit strategies. In a multiperiod setting, the benefit algorithm must specify a level of benefits for each week of unemployment. In practice, most government benefit schemes are quite simple. The U.S. benefit schedule has two steps, with zero benefits in the second step. The behavior of unemployed workers at or near the point at which benefits are "exhausted" has been the focus of considerable empirical study. ${ }^{32}$ In a number of European countries, benefits are reduced more gently through a transition to social assistance, often means-tested welfare programs, Atkinson and Micklewright (1990). ${ }^{33}$

Economists have devoted a great deal of attention to the ideal benefit payout stream as a function of unemployment spell duration. ${ }^{34}$ A key early finding was that UI benefits should optimally decline with duration of unemployment, Shavell and Weiss (1979). The intuition is straightforward. By throwing benefits forward in time in the unemployment spell, workers have less incentive to delay return to work despite currently generous benefits. Reduced future benefits are a threat that may not be realized. Early theoretical contributions, including Shavell and Weiss, assumed away the possibility that the worker could transfer resources across time except through the program under study. The need to repress the possibility of private saving is obvious. The worker, post-separation, has no desire to be squeezed in this way and would

\footnotetext{
${ }^{32}$ Boone and van Ours (2012) provide a summary of this literature as well as their own contribution. See Mortensen (1977) and Meyer (1990) for theoretical and empirical analyses respectively of finite duration benefit schemes.

${ }^{33}$ In the Holzmann et al (2012) data, 16 of the 149 medium and large countries had both unemployment insurance and unemployment assistance (author's calculations from Annex B). Another 6 had only unemployment assistance.

34 Paradigm theoretical studies of optimal unemployment insurance include Azariadis (1975), Baily (1977), Mortensen (1977), Shavell and Weiss (1979), and Hopenhayn and Nicolini (1997). Holmlund (1998), Karni (1999), and Fredriksson and Holmlund (2006) provide excellent reviews.
} 
likely save early UI benefits in order to supplement low benefits in later periods. ${ }^{35}$ This no saving assumption becomes formally awkward in a job displacement setting in which severance pay is almost certainly part of the optimal vector of benefits. ${ }^{36}$

Hopenhayn and Nicolini (1997) analyzed an environment in the spirit of Shavell and Weiss, with no private saving or borrowing, but introduced the possibility that the insurer, presumably the government, can pay out additional benefits early and finance the expense by taxing future worker earnings. The optimal benefit scheme will still involve declining benefits, but, at least in the example developed, at a rate much lower than in the Shavell and Weiss model. The penalty for engaging in longer unemployment spells is spread over both lower expected future unemployment benefits and lower future after-tax earnings. This model also unravels if the worker can privately reallocate resources across periods, and perhaps has assets to start—as the worker would for example with severance payments.

In what may now be considered an early attempt to apply behavioral economics, great effort has also gone into assessing empirically a quite different, discrete payment plan-reemployment bonuses--which offers a lump sum reward if a worker takes another job in a specified time interval. An eye-catching bonus to successful early job finders may accelerate job search and acceptance sufficiently that the bonuses pay for themselves. One early demonstration project to test this conjecture, Illinois, raised hope that the approach might be of practical value, Woodbury and Spiegelman (1987), and led to an ambitious series of demonstration projects that generated much valuable insight into the behavior of the unemployed. ${ }^{37}$ Alas the demonstrations provided no support for the validity of the core proposition. Lump sum bonuses for early job acceptance do not usually pay for themselves.

\footnotetext{
${ }^{35}$ Pavoni (2007) expresses concern that declining benefit schemes in the saving constrained case might lead to unacceptably low levels of benefits for longer unemployment spells. This problem is less serious if the worker is permitted to save.

${ }^{36}$ The fixed sum benefits may be paid out as a lump-sum or as periodic payments, but without reference to unemployment status.

${ }^{37}$ Meyer (1995) provides a thorough review of the demonstration projects and their outcomes.
} 


\section{Saving and Borrowing Strategies}

Mandated saving and borrowing options have received considerable attention as alternative mechanisms for helping unemployed workers smooth consumption in response to earnings shocks, Feldstein and Altman (2007) and Stiglitz and Yun (2005). The theoretical advantages of unemployment savings accounts and severance savings accounts are that they should induce neither (i) search moral hazard nor (ii) firing cost concerns. The reason of course is that the worker already owns the payout, which means the worker cannot capture additional benefit payouts by (inefficiently) remaining unemployed, and the employer cannot avoid benefit payouts by (inefficiently) retaining the worker on the payroll, Parsons (2012b).

Savings accounts may be an excellent substitute for earnings insurance for temporary layoffs in which the worker returns to the contract firm, presumably at the original wage. Unemployment insurance benefits paid to workers on temporary layoffs amount to externally financed vacation pay for a firm's employees, and are likely to be heavily used, Feldstein (1976). The puzzle that remains is why workers and governments are so reluctant to embrace the savings approach-even for temporary layoffs. Savings are however a relatively poor tool for smoothing consumption among long-tenured, displaced workers. That said, if otherwise uninsured, even large shocks are eased by access to savings and credit markets.

As noted in the last section, the worker's ability to save privately fundamentally changes what the government can accomplish. Penalizing extended unemployment through declining consumption, as in Shavell and Weiss (1979) and Hopenhayn and Nicolini (1997), may not be feasible. If the government administrator can observe assets, the declining unemployment benefit plan can be salvaged if the government is willing to tax away positive assets as they accumulate (insuring that none will have any), though that seems unlikely as a public policy.

Insurance plans and saving and borrowing plans are not mutually exclusive, and can be

offered jointly. Worker access to savings instruments changes the profile of optimal 
unemployment insurance benefits. In a model with no moral hazard issues, Shavell and Weiss (1979) demonstrated that positive UI benefits should be offered only after assets are depleted, and then at a fixed benefit level. ${ }^{38}$ First exhausting assets and then accessing insurance makes sense in this model because the worker has no alternative uses for the savings (no retirement or bequest, no risk of future layoffs or wage rate declines). Shavell and Weiss (1979) did not analyze the (search-effort) information-constrained case, but provide a two period model that demonstrates that optimal benefits could either increase or decrease with longer unemployment spells, depending on circumstance such as initial wealth position. Lentz and Tranaes (2005) developed a model of job search and asset choice with fixed unemployment benefits of unlimited duration that generates the plausible prediction that savings will be used to support consumption during an unemployment spell, with search effort increasing as savings dwindle. It is plausible that workers would demand increasing $\mathrm{UI}$ benefits across unemployment spells in this situation, and more generally negotiate benefit plans that are conditioned on asset levels, Rendahl (2012).

If the displaced worker is able to "hide" assets, the nature of the optimal benefit stream is apparently highly model-specific. Kocherlakota (2004, p.541) reported being able to "provide a complete characterization of the optimal contract" if search effort is linear in the probability of securing a job offer (and auxiliary assumptions to deal with the linearity problem are met). "The agent's consumption is constant while he is unemployed, and jumps to a higher constant and history-independent level of consumption when he finds a job." Shimer and Werning (2008) constructed a model with a simple search algorithm and a constant absolute risk aversion utility function which has the convenient property that the solution, in this case of constant benefits throughout the unemployment spell, does not depend on worker wealth-which makes moot the question of whether assets are observed or hidden. Mitchell and Zhang (2010), in a model in many ways similar to Shimer and Werning (2008), concluded that the optimal time profile of

\footnotetext{
${ }^{38}$ Unless assets are sufficiently small that they can effectively be ignored.
} 
benefits should be increasing over the unemployment spell. As a practical matter, approximately 50 percent of workers surveyed in the Displaced Workers Survey exhaust their unemployment benefits (GAO 2012), so the exact shape of the benefit algorithm across unemployment spells may not be as important for permanent layoffs as it could be for temporary layoffs. UI is a fixed sum for UI exhaustees--that is to say, severance pay.

\section{Aging and the Long-tenured Displaced Worker}

Long-tenured displaced workers are, by the very nature of the event, older, and issues of aging and of the job displacement of long-tenured workers overlap. At the simplest level, there is the concern that older workers may be disadvantaged in the labor market. The measured impact of job displacement on older workers who return to work is large and justifies concerns about the welfare of these individuals, Couch (1998), although perhaps no more than younger workers. Chan and Stevens $(1999,2001)$ analyzed the consequence of job loss on older workers (HRS). Among workers in their fifties or beyond, reemployment wage losses of displacement workers were on the order of 24 percent (relative to the not displaced) with a mean duration of unemployment of twelve months, (Chan and Stevens, 1999, pp. 212-213).

Measurement of job displacement effects is difficult, because a greater fraction of older workers than others never return to work. That may be because jobs are scarce or because older workers have access to a variety of alternative support systems, including disability insurance and private and public retirement plans, that ease withdrawal from the labor force. Borrowing against pensions and other post-work income streams can also smooth consumption during unemployment periods if feasible, Stiglitz and Yun (2005). Hairault, Langot, Menard, and Sopraseuth (2012) argue this freedom is critical if the worker is close to retirement.

Recognizing this demographic reality, firms often offer early retirement buyouts, under the belief, apparently true, that workers relatively close to retirement are willing to separate voluntarily with modest inducements (the shadow value of returning to work is low). Public 
systems also treat older workers more generously, reflecting both (i) concern for older individuals and (ii) the possibility that encouraging older workers to leave the labor force will open up jobs for the young (the fixed jobs hypothesis). Early retirement programs, expanded unemployment duration eligibility, reduced active search requirements-all contribute to earlier withdrawal from the work force, OECD (2006).

Older displaced workers do apparently respond robustly to these program incentives and in the expected direction. As Tatsiramos (2010, p.157) summarizes his cross-country findings:

....in countries with relatively more generous unemployment insurance provisions for the older unemployed, which offer a pathway to early retirement, older displaced workers exhibit lower re-employment and higher retirement rates compared to the non-displaced.

The welfare implications of these incentives and responses are less obvious, and may depend on the macroeconomic model felt to be relevant in the economy. 


\section{REFERENCES}

Abbring, Jaap $\mathrm{H}_{\text {.; }}$ van den Berg, Gerard J.; van Ours, Jan C. 2005. "The Effect of Unemployment Insurance Sanctions on the Transition Rate from Unemployment to Employment," Economic Journal, v.115, iss.505 (July 2005): 602-30.

Atkinson, Anthony B. and John Micklewright 1991 "Unemployment Compensation and Labor Market Transitions: A Critical Review." Journal of Economic Literature 29 (December): 1679-1727.

Azariadis, Costas. 1975. "Implicit Contracts and Underemployment Equilibria," Journal of Political Economy, 83 (December): 1183-1202.

Baily, Martin Neil. 1977. "Unemployment Insurance.as Insurance for Workers" Industrial and Labor Relations Review 30 (July): 495-504.

Baily, Martin Neil, Gary Burtless, and Robert E. Litan. 1993. Growth with Equity: Economic Policymaking for the Next Century, Washington, DC.: 110-141.

Besley, Timothy and Stephen Coate. 1992. "Workfare versus Welfare: Incentive Arguments for Work Requirements in Poverty-Alleviation Programs," American Economic Review 82: 249-261.

Bishow, John, and Donald O. Parsons. 2004. "Trends in Severance Pay Coverage in the United States. 1980-2001" (May) Available at SSRN: http://ssrn.com/abstract=878144

Black, Dan A., Jeffrey A. Smith, Mark C. Berger, and Brett J. Noel. 2003. "Is the Threat of Reemployment Services More Effective than the Services Themselves? Evidence from Random Assignment in the UI System," American Economic Review, Vol. 93.4 (November): 1313-1327.

Blanchard, Olivier J., and Jean Tirole. 2008. "The Joint Design of Unemployment Insurance and Employment Protection: A First Pass," Journal of the European Economic Association, v.6.1 (March): 45-77.

Bloemen, Hans G., and Elena G. F. Stancanelli. 2005. "Financial Wealth, Consumpton Smoothing and Income Shocks Arising from Job Loss." Economica v.72. 431-452.

Blundell, Richard; Luigi Pistaferri, and Ian Preston. 2008. "Consumption Inequality and Partial Insurance." American Economic Review, v.98.5 (December): 1887-1921.

Boone, Jan, and Jan C. van Ours, 2012 "Why Is There a Spike in the Job Finding Rate at Benefit Exhaustion?" De Economist v.160.4 (December): 413-38.

Browning, Martin, and Thomas F. Crossley. 2001. "Unemployment Insurance Benefit Levels and Consumption Changes," Journal of Public Economics v.80.1, (April ): 1-23.

Browning, Martin, and Thomas F. Crossley, 2008. "The Long-Run Cost of Job Loss as Measured by Consumption Changes," Journal of Econometrics, v.145.1-2, (July): 10920. 
Buehn, Andreas, and Friedrich Schneider. 2012. "Shadow Economies around the World: Novel Insights, Accepted Knowledge, and New Estimates." International Tax and Public Finance, (February): 139-71.

Bureau of Labor Statistics (U.S. Department of Labor). 2012. Worker Displacement: 20092011. BLS news release USDL-12-1719.

Card, David; Raj Chetty, and Andrea Weber. 2007. "Cash-on-Hand and Competing Models of Intertemporal Behavior: New Evidence from the Labor Market." Quarterly Journal of Economics, v.122.4 (November): 1511-60.

Chan, Sewin, and Ann Huff Stevens. 1999. "Employment and Retirement Following a LateCareer Job Loss," American Economic Review, v. 89.2, (May): 211-16.

Chan, Sewin, and Ann Huff Stevens. 2001. "Job Loss and Employment Patterns of Older Workers," Journal of Labor Economics, v.19.2 (April): 484-521.

Chetty, Raj. 2008. "Moral Hazard versus Liquidity and Optimal Unemployment Insurance," Journal of Political Economy. v.116.2 (April): 173-234.

Cochrane, John H. 1991. "A Simple Test of Consumption Insurance." Journal of Political Economy, v. 99.5 (October): pp. 957-76.

Couch, Kenneth A. 1998. "Late Life Job Displacement," Gerontologist 38.1 (February): 7-17.

Couch, Kenneth A. and Dana W. Placzek. 2010. "Earnings Losses of Displaced Workers Revisited," American Economic Review v100.1: 572-589.

Cullen, Julie Berry, and Jonathan Gruber. 2000. "Does Unemployment Insurance Crowd Out Spousal Labor Supply?" Journal of Labor Economics, v.18.3, (July): 546-72.

Davis, Steven, and Till Von Wachter. 2011. "Recessions and the Costs of Job Loss," Brookings Papers on Economic Activity. (Fall): 1-55.

Emerson, Michael. 1988. "Regulation or Deregulation of the Labour Market; Policy Regimes for the Recruitment and Dismissal of Employees in the Industrialized Countries," European Economic Review 32 (1988): 775-817.

Engen, Eric M., and Jonathan Gruber. 2001. "Unemployment Insurance and Precautionary Saving." Journal of Monetary Economics, v.47.3 (June): 545-579.

Fallick, Bruce C. 1996. "A Review of the Recent Empirical Literature on Displaced Workers." Industrial and Labor Relations Review, v.50.1 (October): 5-16.

Farber, Henry S. 2004 Job Loss in the United States, 1981-2001 Accounting for Worker Wellbeing, Research in Labor Economics, v.23. 69-117.

Feldstein, Martin. 1976. "Temporary Layoffs in the Theory of Unemployment", Journal of Political Economy, Vol. 84 (October): 937-958.

Feldstein, Martin, and Daniel Altman. 2007. "Unemployment Insurance Savings Accounts," Tax Policy and the Economy v.21, 35-63.

Flemming, J.S., 1978. "Aspects of Optimal Unemployment Insurance." Journal of Public Economics, v.10. 403-425. 
Fredriksson, Peter, and Bertil Holmlund. 2006. "Improving Incentives in Unemployment Insurance: A Review of Recent Research," Journal of Economic Surveys, vol.20.3: 357386.

Government Accountability Office (U.S). 2012. Unemployment Insurance: Economic Circumstances of Individuals Who Exhausted Benefits, Report to the Chair, Committee on Finance, U.S. Senate, GAO-12-408 (February).

Grubb, David. 2000. "Eligibility Criteria for Unemployment Benefits." OECD Economic Studies, iss.31, 147-84.

Gruber, Jonathan. 1997. "The Consumption Smoothing Benefits of Unemployment Insurance." American Economic Review v 87.11 (March): 192-205.

Gruber, Jonathan. 2001. "The Wealth of the Unemployed." Industrial and Labor Relations Review v.55.1 (October): 79-94.

Hairault, Jean-Olivier, Francois Langot, Sebastien Menard, and Thepthida Sopraseuth. 2012. "Optimal Unemployment Insurance for Older Workers," Journal of Public Economics v.96.5-6, (June): 509-19.

Hansen, Gary D. and Ayse Imrohoroglu. 1992. "The Role of Unemployment Insurance in an Economy with Liquidity Constraints and Moral Hazard," Journal of Political Economy, v.100.1 (February): 118-42.

Heckman, James J., and Carmen Pagés. 2004. "Introduction," in Heckman and Pagés, eds., Law and Employment: Lessons from Latin America and the Caribbean, Chicago, The University of Chicago: 1-107.

Helwig, Ryan T. 2001. "Worker Displacement in a Strong Labor Market." Monthly Labor Review, v.124.6 (June): 13-28.

Holmlund, Bertil. 1998. "Unemployment Insurance in Theory and Practice," Scandinavian Journal of Economics.100(1): 113-141.

Holzmann, Robert, Yann Pouget, Michael Weber, and Milan Vodopivec. 2012. "Severance Pay Programs around the World: History, Rationale, Status, and Reforms" In Robert Holzmann and Milan Vodopivec, eds., Reforming Severance Pay: An International Perspective, Washington, DC: World Bank: 17-120.

Hopenhayn, Hugo A. and Juan Pablo Nicolini. 1997. "Optimal Unemployment Insurance," Journal of Political Economy. 105.2 (April): 412-438.

International Labour Office (ILO), Unemployment Insurance Schemes. Studies and Reports, New Series, No. 42, Geneva International Labour Office, 1955.

Jacobson, Louis S., Robert J. LaLonde, and Daniel G. Sullivan, 1993. "Earnings Losses of Displaced Workers, American Economic Review v.83.4 (September): 685-709. 1993a.

Jacobson, Louis S., LaLonde, Robert J. and Sullivan, Daniel G. 1993. "Long-term Earnings Losses of High-seniority Displaced Workers." Economic Perspectives 17 (November/ December): 2-20. 1993b.

Karni, Edi, 1999. 2006. "Optimal Unemployment Insurance: A Survey." Southern Economic Journal, 66 (October): 442-65. 
Kletzer, Lori G. 1998. "Job Displacement." Journal of Economic Perspectives v12, n1 (Winter): 115-36.

Kling, Jeffrey R. 2006. "Fundamental Restructuring of Unemployment Insurance: Wage-Loss Insurance and Temporary Earnings Replacement Accounts," The Hamilton Project, Brookings Institution, Discussion Paper 2006-05 (September).

Kocherlakota, Narayana R. 2004. "Figuring Out the Impact of Hidden Savings on Optimal Unemployment Insurance." Review of Economic Dynamics. v.7.3 (July): 541-54.

Kreiner, Claus Thustrup and Torben Tranaes. 2005. "Optimal Workfare with Voluntary and Involuntary Unemployment". Scandinavian Journal of Economics, 107.3 (September): 459-474.

Kuhn, Peter J. 2002 "Summary and Synthesis." in 2002. Losing Work, Moving On: International Perspectives on Worker Displacement, W.E. Upjohn Institute for Employment Research, Kalamazoo, Michigan. 1-103.

LaLonde, Robert J. 2007. "The Case for Wage Insurance," Maurice R. Greenberg Center for Geoeconomic Studies at the Council on Foreign Relations. http://www.cfr.org/publication/13661/case for wage insurance.html,

Lazear, Edward P. 1990. "Job Security Provisions and Employment," Quarterly Journal of Economics 105 (August), 699-726.

Lentz, Rasmus, and Torben Tranæs. 2005. "Job Search and Savings: Wealth Effects and Duration Dependence," Journal of Labor Economics v.23.3 (July): 467-89.

Mace, Barbara J. 1991.."Full Insurance in the Presence of Aggregate Uncertainty." Journal of Political Economy. v.99.5 (October): 928-56.

Malcomson, J. 1999. "Individual Employment Contracts," in Orley Ashenfelter and David Card, eds. Handbook of Labor Economics, Vol. IIIB, Chapter 35, North Holland Press pp.2291-2372.

Mitchell, Matthew, and Yuzhe Zhang. 2010. "Unemployment Insurance with Hidden Savings," 2010. Journal of Economic Theory (November) v.145.6 (November): 2078-2107.

Mortensen, Dale T., 1977. "Unemployment Insurance and the Job Search Decision" Industrial and Labor Relations Review v30 (July): 505-517.

Meyer, Bruce D., 1990. "Unemployment Insurance and Unemployment Spells," Econometrica, (July), v. 58.4, 757-82.

Meyer, Bruce D., 1995. "Lessons from the U.S. Unemployment Insurance Experiments," Journal of Economic Literature, (March), v.33.1, 91-131.

Nichols, Albert L., and Richard J. Zeckhauser, 1982 "Targeting Transfers through Restrictions on Recipients," American Economic Review, v.72.2 (May): 372-77.

OECD. 2006. Employment Outlook 2006. 
Parsons, Donald O. 1986. "The Employment Relationship: Job Attachment, Work Effort, and the Nature of Contracts" in Orley Ashenfelter and Richard Layard, eds. Handbook of Labor Economics, Vol. II, North Holland Press: 789-848.

Parsons, Donald O. 2000. "Wage Insurance: A Policy Review," in Research in Employment Policy, 2: 119-140.

Parsons, Donald O. 2005. "Benefit Generosity in Voluntary Severance Plans: The U.S. Experience" (December). http://ssrn.com/abstract=877903.

Parsons, Donald O. 2012a. "Mandated Severance Pay and Firing Cost Distortions: A Critical Review of the Evidence," Chapter 3 in Robert Holzmann and Milan Vodopivec, eds., Reforming Severance Pay: An International Perspective, Washington, DC: World Bank, 2012, 121-157.

Parsons, Donald O. 2012b. "The Firing Cost Implications of Alternative Severance Pay Designs" Chapter 4 In Robert Holzmann and Milan Vodopivec, eds., Reforming Severance Pay: An International Perspective, Washington, DC: World Bank, 2012, 159-176.

Parsons, Donald O. 2013. "Understanding Severance Pay," Cuadernos de Economía (Spanish Journal of Economics and Finance) Elsevier. v.36, no, 106 Sept-Dec, 2013: 155-165.

Parsons, Donald O. 2014a. "Job Displacement Insurance: A Policy Taxonomy," mimeo, Economics Department, George Washington University.

Parsons, Donald O. 2014b. "The Simple Analytics of Job Displacement Insurance." mimeo, George Washington University.

Pavoni, Nicola. 2007. "On Optimal Unemployment Compensation." Journal of Monetary Economics v. 54.6 (September): 1612-30.

Pissarides, Christopher A. 2010 “Why Do Firms Offer ‘Employment Protection'?” Economica 77, 613-636

Pita, Cristina, "Advance Notice and Severance Pay Provisions in Contracts," Monthly Labor Review 119 (July 1996):

Ravallion, Martin; 1991. "Reaching the Rural Poor through Public Employment: Arguments, Evidence, and Lessons from South Asia," World Bank Research Observer, v.6.2 (July): 153-75.

Rendahl, Pontus. 2012. "Asset-Based Unemployment Insurance." International Economic Review, August 2012, v. 53.3 (August): 743-70.

Riddell, Chris, and Peter J. Kuhn. 2010 "The Long-Term Effects of Unemployment Insurance: Evidence from New Brunswick and Maine, 1940-1991," Industrial and Labor Relations Review, v.63.2 (January): 183-204.

Rogerson, Richard; and Martin Schindler. 2002. "The Welfare Costs of Worker Displacement," Journal of Monetary Economics v49.6 (September): 1213-34.

Rosen, Sherwin. 1985. "Implicit Contracts: A Survey," Journal of Economic Literature 23 (September): 1144-1175. 
Ruhm, Christopher J. 1991. "Are Workers Permanently Scarred by Job Displacements?" American Economic Review, March 1991, v. 81.1, pp. 319-24.

St.Louis, Robert D., Paul L. Burgess, and Jerry L. Kingston. 1986. "Reported vs. Actual Job Search by Unemployment Insurance Claimants." Journal of Human Resources v21.1 (Winter): 92-117.

Salanié, Bernard. 2005. The Economics of Contracts: A Primer, Second Edition, MIT Press.

Shavell, Steven and Laurence Weiss. 1979. "The Optimal Payment of Unemployment Insurance Benefits over Time." Journal of Political Economy 87 (December): 1347-1362.

Shimer, Robert, and Ivan Werning. 2008. "Liquidity and Insurance for the Unemployed," American Economic Review. v. 98.5 (December): 1922-42.

Stephens, Melvin Jr. 2001. "The Long-Run Consumption Effects of Earnings Shocks," Review of Economics and Statistics, 83.1, (February): 28-36.

Stephens, Melvin Jr. 2004. "Job Loss Expectations, Realizations, and Household Consumption Behavior." Review of Economics and Statistics. v.86.1 (February): 253-69.

Stevens, Ann Huff. 1997. "Persistent Effects of Job Displacement: The Importance of Multiple Job Losses," Journal of Labor Economics, v.15.1, Part 1 (January): 165-88.

Stiglitz, Joseph E. 1969. "Behavior Towards Risk with Many Commodities," Econometrica, Vol. 37.4 (October): 660-667.

Stiglitz, Joseph E., and Jungyoll Yun. 2005. "Integration of Unemployment Insurance with Retirement Insurance." Journal of Public Economics v. 89.11-12, (December): 2037-67.

Sullivan, James X. 2008. "Borrowing during Unemployment: Unsecured Debt as a Safety Net." Journal of Human Resources. v.43.2 (Spring): 383-412.

Tatsiramos, Konstantinos, 2010. "Job Displacement and the Transitions to Re-employment and Early Retirement for Non-employed Older Workers," European Economic Review v. 54.4 (May): 517-35.

Willoughby, William Franklin. 1897. "Insurance Against Unemployment." Political Science Quarterly, v.12.3 (September): 476-489.

Woodbury, Stephen A., and Robert G. Spiegelman. 1987. "Bonuses to Workers and Employers to Reduce Unemployment: Randomized Trials in Illinois," American Economic Review, 77.4 (September): 513-30. 
TABLE 1

Job Displacement Losses among Long Tenured Workers

\begin{tabular}{|c|c|c|c|c|}
\hline Study & $\begin{array}{c}\text { Data } \\
\text { Source }\end{array}$ & $\begin{array}{c}\text { Sample } \\
\text { Restrictions }\end{array}$ & $\begin{array}{c}\text { Short term } \\
\text { Earnings loss }\end{array}$ & $\begin{array}{c}\text { Long term } \\
\text { Earnings Loss }\end{array}$ \\
\hline $\begin{array}{l}\text { Jacobson, } \\
\text { LaLonde, and } \\
\text { Sullivan (1993) }\end{array}$ & $\begin{array}{l}\text { ADMIN. } \\
\text { DATA PA }\end{array}$ & $\begin{array}{c}\text { Tenure 6+ } \\
\text { Mass layoffs }\end{array}$ & (Q5\% & $25 \% \quad(t+6)$ \\
\hline $\begin{array}{l}\text { Couch and } \\
\text { Placzek (2011) }\end{array}$ & $\begin{array}{l}\text { ADMN. } \\
\text { DATA CT }\end{array}$ & $\begin{array}{c}\text { Tenure 6+ } \\
\text { Mass layoffs }\end{array}$ & $\begin{array}{r}32-33 \% \\
(\mathrm{Q} 1)\end{array}$ & $\begin{array}{r}13-15 \% \\
(t+6)\end{array}$ \\
\hline Ruhm (1991) & PSID & $\begin{array}{c}\text { Plant closings, } \\
\text { permanent } \\
\text { layoff }\end{array}$ & $\begin{array}{l}17.5 \% \\
(t+1)\end{array}$ & $\begin{array}{l}14.7 \% \\
(t+4)\end{array}$ \\
\hline Stevens (1997) & PSID & $\begin{array}{c}\text { Tenure } 3+ \\
\text { Plant closings, } \\
\text { permanent } \\
\text { layoff }\end{array}$ & $26 \%$ & $11 \%$ \\
\hline Farber (2004) & DWS & $\begin{array}{l}\text { Slack work, } \\
\text { Plant Closing, } \\
\text { position/shift } \\
\text { abolished }\end{array}$ & $\begin{array}{cc}32.4 \% & \\
& \text { Emp. loss } \\
7.8 \% & \\
& \text { Wage loss } \\
& \text { FT To FT } \\
\text { (3 years or less) }\end{array}$ & NA \\
\hline
\end{tabular}


Table 2

Job Displacement Insurance Coverage Worldwide (Countries with populations exceeding 1 million in 2009)

\begin{tabular}{|c|c|}
\hline & Countries \\
\hline ONLY STATUTORY SEVERANCE & $69(46.3 \%)$ \\
\hline $\begin{array}{l}\text { BOTH STATUTORY SEVERANCE PAY } \\
\text { AND UI/UA }\end{array}$ & $61(40.9 \%)$ \\
\hline ONLY UI/UA & $13(8.7 \%)$ \\
\hline $\begin{array}{l}\text { With significant collectively bargained } \\
\text { severance }\end{array}$ & 12 \\
\hline $\begin{array}{l}\text { With NO significant collectively } \\
\text { bargained severance }\end{array}$ & 1 \\
\hline NONE & $6 \quad(4.0 \%)$ \\
\hline TOTAL & 149 \\
\hline
\end{tabular}

Source: Author's calculation from amended Holzmann et al (2012, Annex B) 
Table 3

Consumption Losses among Involuntarily Displaced Workers

\begin{tabular}{|c|c|c|c|c|}
\hline Study & $\begin{array}{l}\text { Countryl } \\
\text { Data }\end{array}$ & $\begin{array}{c}\text { Sample } \\
\text { Restrictions }\end{array}$ & $\begin{array}{l}\text { Consumption } \\
\text { Losses }\end{array}$ & Remarks \\
\hline \multicolumn{5}{|c|}{ A. Consumption Losses Following Displacement } \\
\hline $\begin{array}{l}\text { Cochrane } \\
\text { (1991) }\end{array}$ & $\begin{array}{l}\text { U.S.I } \\
\text { PSID }\end{array}$ & $\begin{array}{l}\text { Involuntary job } \\
\text { loss }\end{array}$ & $24-27 \%$ & \\
\hline $\begin{array}{l}\text { Stephens } \\
(2001)\end{array}$ & $\begin{array}{l}\text { U.S.I } \\
\text { PSID }\end{array}$ & $\begin{array}{l}\text { Plant closings } \\
\text { and permanent } \\
\text { layoffs }\end{array}$ & $\begin{array}{l}11.0 \% \\
\quad(6+\text { years }) \\
9.8 \% \\
\text { (all years) }\end{array}$ & $\begin{array}{l}\text { Earnings decline } \\
21.9 \% \text { (6+years) }\end{array}$ \\
\hline $\begin{array}{l}\text { Stephens } \\
(2004)\end{array}$ & $\begin{array}{l}\text { U.S.I } \\
\text { PSID and } \\
\text { HRS }\end{array}$ & $\begin{array}{l}\text { Older Workers } \\
\text { (50 to early 60s) } \\
\text { Business } \\
\text { Closed/Moved } \\
\text { or Laid off }\end{array}$ & $\begin{array}{ll}15.0 \% & \text { (PSID) } \\
17.7 \% & \text { (HRS) }\end{array}$ & $\begin{array}{l}\text { Within one year } \\
\text { of displacement }\end{array}$ \\
\hline $\begin{array}{l}\text { Browning and } \\
\text { Crossley } \\
(2008)\end{array}$ & $\begin{array}{l}\text { Canada/ } \\
\text { COEP }\end{array}$ & $\begin{array}{l}\text { Plant closure } \\
\text { and mass layoff } \\
\text { \&tenure greater } \\
\text { than } 10 \text { years } \\
\text { \&age greater } \\
\text { than } 40\end{array}$ & $\begin{array}{l}6.4 \% \\
10.4 \% \\
9.3 \%\end{array}$ & $\begin{array}{l}\text { Canadian Out of } \\
\text { Employment } \\
\text { Panel (COEP) } \\
\text { Total } \\
\text { Expenditures }\end{array}$ \\
\hline $\begin{array}{l}\text { Bloemen and } \\
\text { Stancanelli } \\
\text { (2005) }\end{array}$ & $\begin{array}{l}\text { U.K.I } \\
\text { LSUS }\end{array}$ & $\begin{array}{l}\text { Unemployed for } \\
\text { at least three } \\
\text { months }\end{array}$ & $\begin{array}{ll}17 \% & \\
& \text { (Simple } \\
& \text { Average) }\end{array}$ & $\begin{array}{l}\text { Living } \\
\text { Standards } \\
\text { During } \\
\text { Unemployment } \\
\text { Survey }\end{array}$ \\
\hline \multicolumn{5}{|c|}{ B. Responsiveness of Consumption to Job Displacement Insurance } \\
\hline $\begin{array}{l}\text { Browning and } \\
\text { Crossley } \\
(2001)\end{array}$ & $\begin{array}{l}\text { Canada/ } \\
\text { COEP }\end{array}$ & $\begin{array}{l}\text { Permanent } \\
\text { Layoff } \\
\text { At least six } \\
\text { months } \\
\text { unemployment }\end{array}$ & $\begin{array}{l}0.05 \\
\text { Consumption/ } \\
\text { UI RR elasticity } \\
0.17 \\
\text { Consumption/ } \\
\text { UI RR elasticity } \\
\text { if no assets and } \\
\text { respondent sole } \\
\text { breadwinner }\end{array}$ & $\begin{array}{l}\text { Canadian Out of } \\
\text { Employment } \\
\text { Panel (COEP) } \\
\text { Total } \\
\text { Expenditure }\end{array}$ \\
\hline $\begin{array}{l}\text { Bloemen and } \\
\text { Stancanelli } \\
(2005)\end{array}$ & $\begin{array}{l}\text { U.K.I } \\
\text { LSUS }\end{array}$ & $\begin{array}{l}\text { Unemployed for } \\
\text { at least three } \\
\text { months }\end{array}$ & $\begin{array}{l}\text { UI RR effect } \\
\text { insignificant } \\
\text { except } \\
0.2\end{array}$ & $\begin{array}{l}\text { Severance pay } \\
\text { has sig, positive } \\
\text { impact on } \\
\text { consumption }\end{array}$ \\
\hline
\end{tabular}




\begin{tabular}{|c|c|c|c|c|}
\hline & & & $\begin{array}{l}\text { Consumption/ } \\
\text { UI RR elasticity } \\
\text { if zero assets, } \\
\text { no severance } \\
\text { and sole } \\
\text { breadwinner }\end{array}$ & \\
\hline \multicolumn{5}{|c|}{ C. Responsiveness of Consumption to Permanent/Transitory Earnings Shocks } \\
\hline $\begin{array}{l}\text { Blundell, } \\
\text { Pistaferri, and } \\
\text { Preston (2008) }\end{array}$ & $\begin{array}{l}\text { U.S.I } \\
\text { PSID } \\
\text { and } \\
\text { CEX }\end{array}$ & $\begin{array}{l}\text { Distinguish } \\
\text { transitory and } \\
\text { permanent } \\
\text { shocks }\end{array}$ & $\begin{array}{l}\text { 0.64 } \\
\text { Elasticity of } \\
\text { consumption } \\
\text { change to perm } \\
\text { income change } \\
0.05 \\
\text { Elasticity of } \\
\text { consumption } \\
\text { change to } \\
\text { transitory } \\
\text { income change }\end{array}$ & $\begin{array}{l}\text { Heterogeneity } \\
\text { important }\end{array}$ \\
\hline
\end{tabular}


FIGURE 1

THE IMPACT OF JOB DISPLACEMENT 2009-2011

LONG-TENURED WORKERS IN JANUARY 2012

Panel A: Labor Force Status

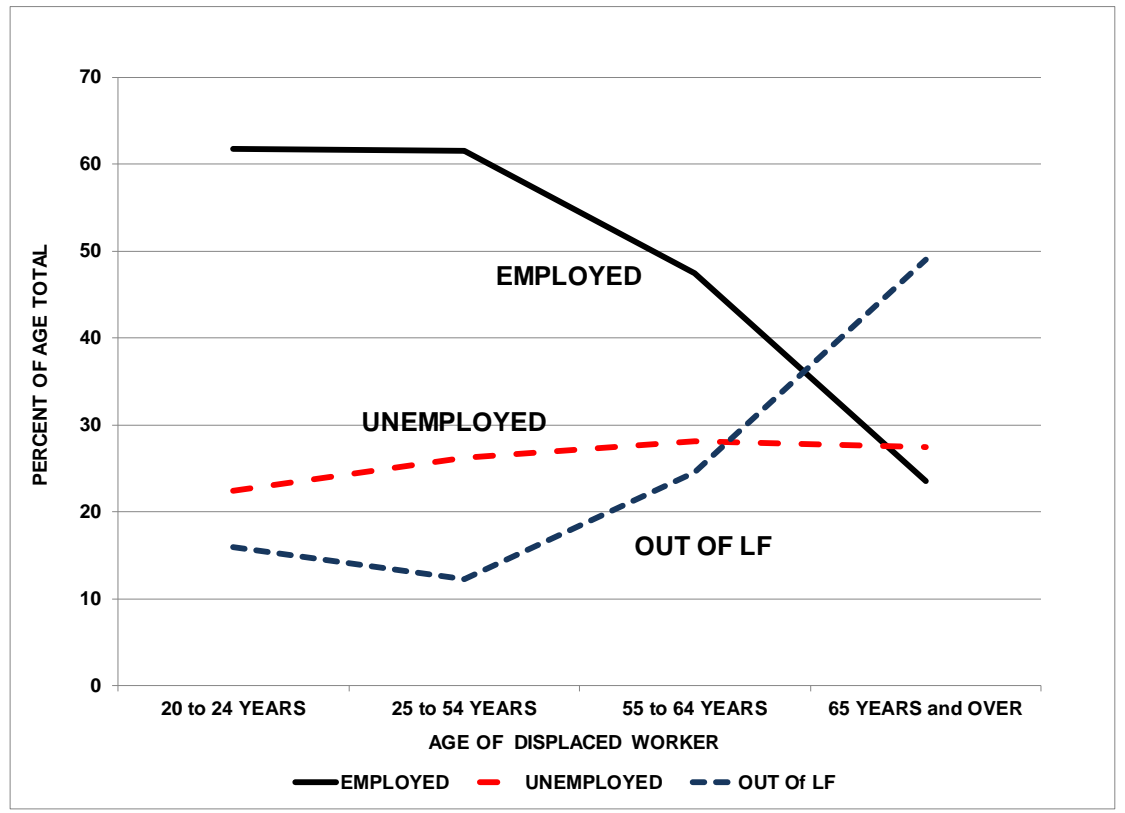

Panel B: Distribution of Wage Changes

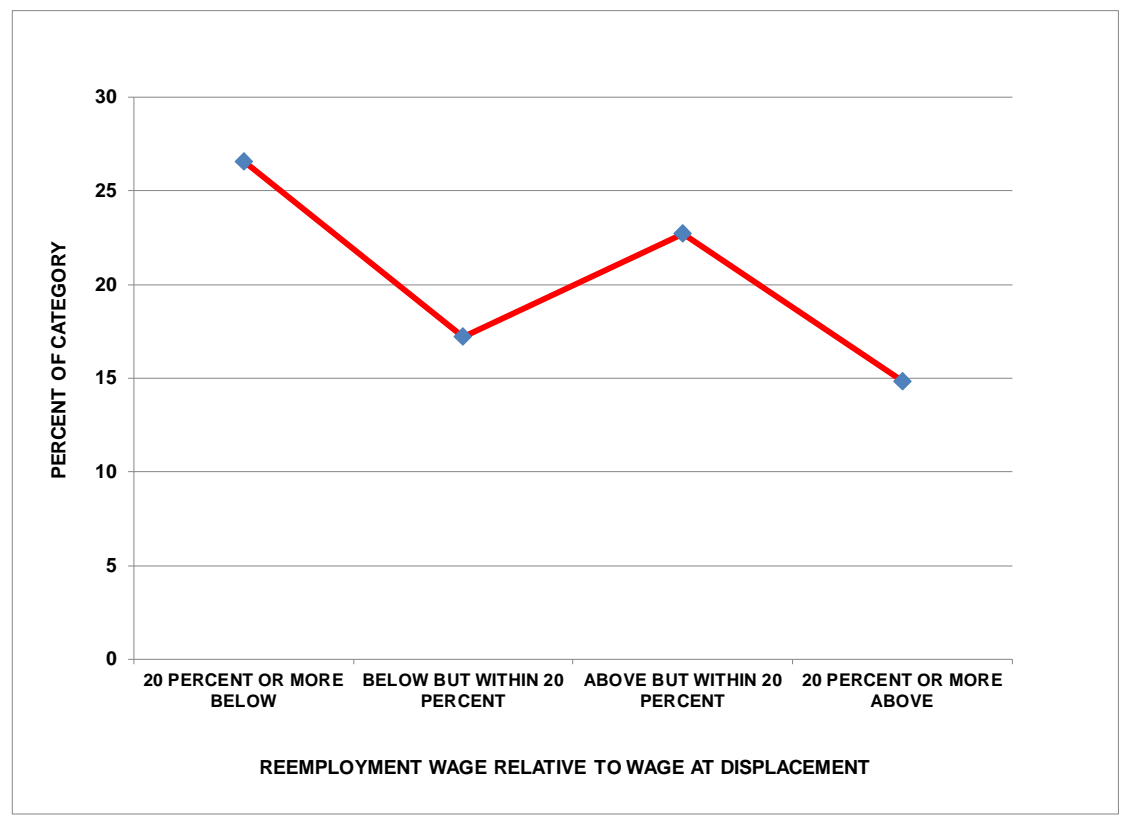


FIGURE 2

FRACTIONAL EARNINGS LOSSES AMONG FULL-TIME WORKERS BY TENURE TEN DW SURVEYS, FARBER (2004. TABLE 3)

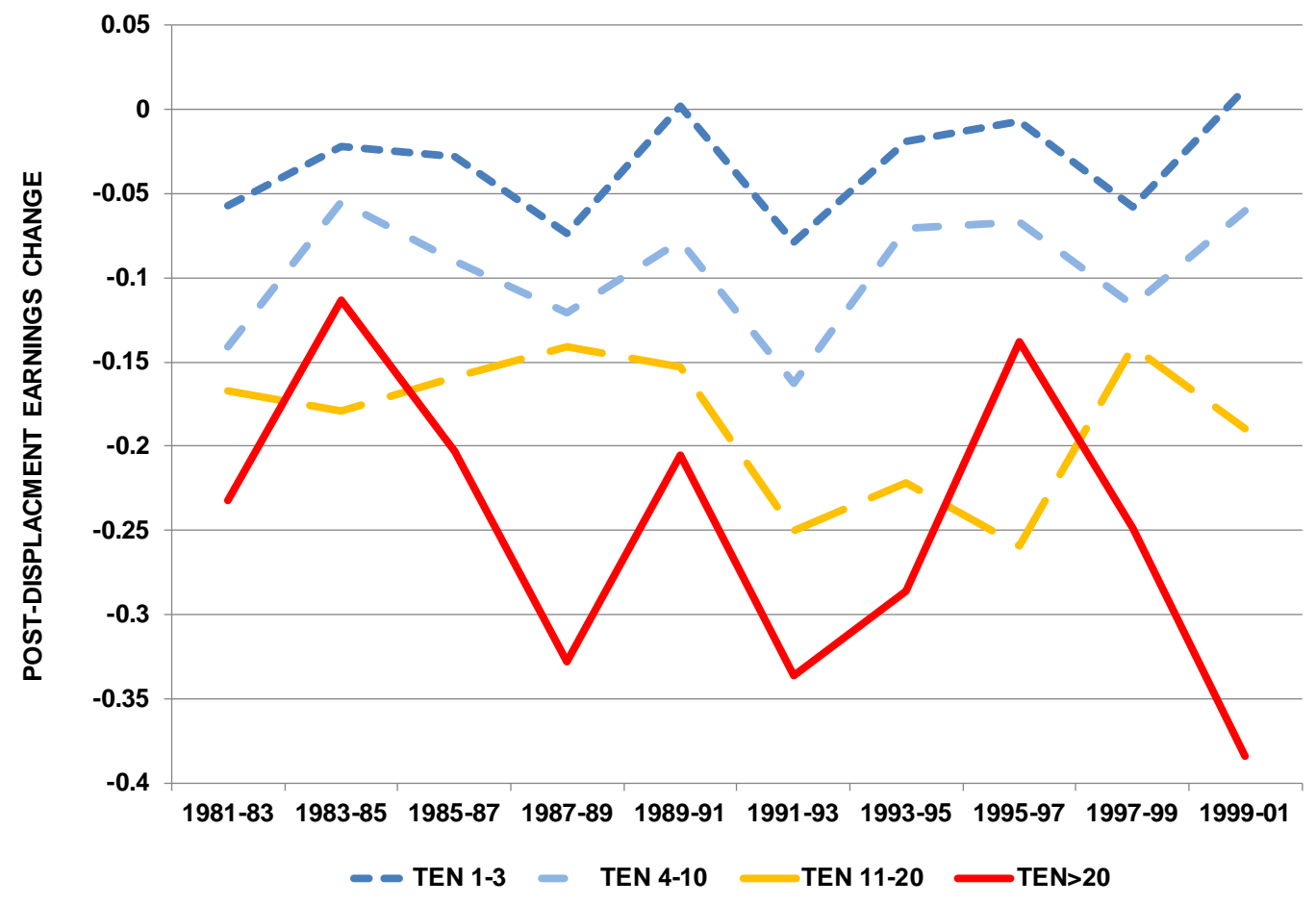




\section{FIGURE 3}

SEVERANCE GENEROSITY (WEEKS OF PAY) AT FIVE AND TWENTY YEARS OF SERVICE MEDIUM AND LARGE COUNTRIES, HOLZMANN ET AL (2012, ANNEX B)

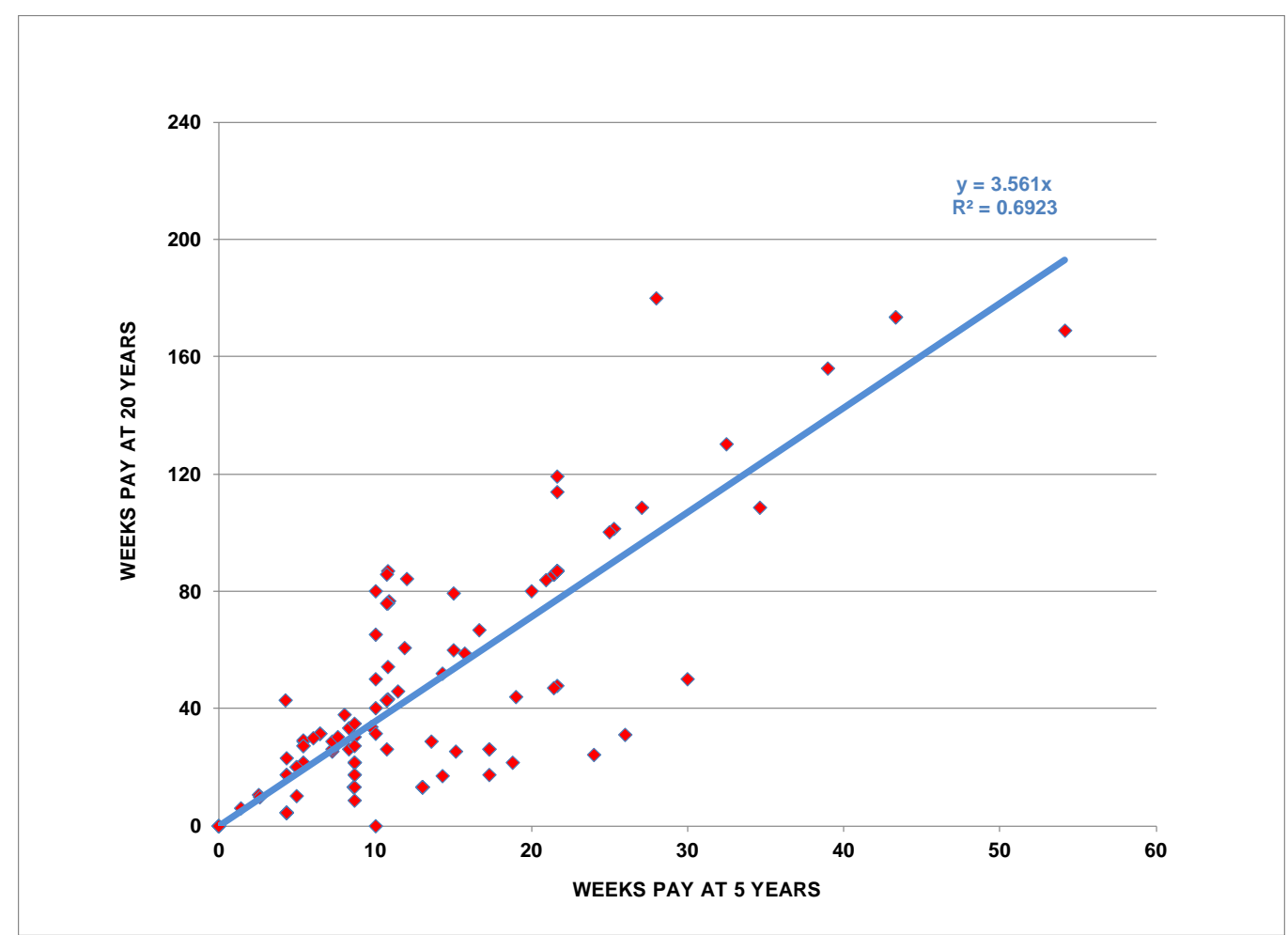

